\title{
Current Knowledge on the Vascular Effects of Menthol
}

\begin{abstract}
Henrique Silva ${ }^{1,2,3,4 *}$
${ }^{1}$ CBIOS - Universidade Lusófona's Research Center for Biosciences and Health Technologies, Lisboa, Portugal, ${ }^{2}$ Pharmacol. Sc Depart - Universidade de Lisboa, Faculty of Pharmacy, Lisboa, Portugal, ${ }^{3}$ Department for Management of Science and Technology Development, Ton Duc Thang University, Ho Chi Minh City, Vietnam, ${ }^{4}$ Faculty of Pharmacy, Ton Duc Thang University, Ho Chi Minh City, Vietnam
\end{abstract}

Menthol is a monoterpene alcohol, widely used in several food and healthcare products for its particular odor and flavor. For some decades, menthol has been known to act on the vasculature directly in the endothelium and vascular smooth muscle, with recent studies showing that it also evokes an indirect vascular response via sensory fibers. The mechanisms underlying menthol's vascular action are complex due to the diversity of cellular targets, to the interplay between signaling pathways and to the variability in terms of response. Menthol can evoke either a perfusion increase or decrease in vivo in different vascular territories, an observation that warrants a critical discussion. Menthol vascular actions in vivo seem to depend on whether the vascular territory under analysis has been directly provoked with menthol or is located deep/distant to the application site. Menthol increases perfusion of directly provoked skin regions due to a complex interplay of increased nitric oxide (NO), endothelium-derived hyperpolarization factors (EDHFs) and sensory nerve responses. In non-provoked vascular beds menthol decreases perfusion which might be attributed to heat-conservation sympatheticallymediated vasoconstriction, although an increase in tissue evaporative heat loss due the formulation ethanol may also play a role. There is increasing evidence that several of menthol's cellular targets are involved in cardiovascular diseases, such as hypertension. Thus menthol and pharmacologically-similar drugs can play important preventive and therapeutic roles, which merits further investigation.

Keywords: menthol, vascular, vasoconstriction, vasodilation, TRPM8 channels, calcium channels, review

\section{GENERAL CHARACTERIZATION OF MENTHOL}

Menthol is a cyclic monoterpene alcohol present mainly in several species of Mentha herbs (mints), and is responsible for their distinctive cool/fresh odor and flavor (Eccles, 1994). The main source of menthol is peppermint, introduced in the European medical culture in the $18^{\text {th }}$ century. Peppermint essential oil has been used throughout the centuries for its therapeutic

Abbreviations: BP, blood pressure; CGRP, calcitonin gene-related peptide; CM, calmodulin; EDHFs, endothelium-derived hyperpolarization factors; MLC, myosin light chain; MLCP, myosin light chain phosphatase; MLCK, myosin light chain kinase; NO, nitric oxide; NOS, nitric oxide synthase; $\mathrm{PIP}_{2}$, phosphatidylinositol-4,5-biphosphate; ROCK, Rho-associated protein kinase; ROS, reactive oxygen species; SR, sarcoplasmic reticulum; VSM, vascular smooth muscle. 
properties in a variety of medical disorders including gastrointestinal, respiratory, reproductive and inflammatory, among others (Lawrence, 2006). Menthol possesses particular odorant, flavoring and therapeutic properties, which justifies its use in many food and healthcare products, including cosmetics, dentifrices, analgesics, cough medicines, as well as in tobacco products (Craighead and Alexander, 2016).

Menthol (5-methyl-2-propan-2-ylcyclohexan-1-ol) possesses three stereogenic centers and, therefore, four pairs of optical isomers: $(+)$ - and (-)-menthol, (+)- and (-)-neomenthol, (+)and (-)-neoisomenthol, and (+)- and (-)-isomenthol, whose structures are shown in Figure 1. Menthol has a molecular weight of $156.26 \mathrm{~g} / \mathrm{mol}$, is solid at room temperature (melting point: $\left.41-44^{\circ} \mathrm{C}\right)$, is not completely soluble in water $(431 \mathrm{mg} / \mathrm{L}$ at $20^{\circ} \mathrm{C}$ ), but is a freely soluble ethanol (Kamatou et al., 2013). It has a $\log$ (octanol/water) value of 3.4, which means that it is a lipophilic molecule capable of interacting with biological membranes (Turina et al., 2006). Menthol was first isolated in a pure form in 1771 by Heidelberg-born chemist and physician Hieronymus David Gaubius (1705-1780). The first studies on its characterization and structure determination were published by Oppenheim, Beckett, Moriya and Atkinson in 18621882 (Schaefer, 2015). The only naturally-occurring enantiomer, isolated from a variety of mint herbs species, is (-)-menthol. The other optical isomer, (+)-menthol, is an industrial synthesis product that yields the racemic $( \pm)$-mixture (Oertling et al., 2007). (-)-menthol has a fresh, sweet, minty odor, while that produced by $(+)$-menthol is dusty, herbal and only fairly minty (Eccles et al., 1988). Furthermore, (+)-menthol pharmacological properties are vastly reduced compared to $(-)$-menthol (Eccles et al., 1988; Bhatia et al., 2008; Lawrence et al., 2011), and are reported as toxic (Petrowitz, 1980). Given its popularity, menthol is a highly demanded molecule, which justifies why most menthol today is not extracted from plants, but obtained by chemical synthesis (Schaefer, 2015).

Menthol absorbed via the gastrointestinal tract, skin or airways is transported to the liver by the circulation, where it is mainly metabolized. When taken orally, menthol undergoes marked rapid absorption in the small intestine (Hiki et al., 2011), whereas transdermal absorption is considerably slower and less extensive (Valente et al., 2015). Given its highly lipophilic nature, it is metabolized by uridine diphosphateglucuronyltransferase to form menthol glucuronide (phase II reaction), which is then delivered to the kidneys for urinary excretion. This reaction is quick enough to maintain menthol at low (or undetectable) levels in venous blood, unlike the high levels detected of menthol glucuronide (Gelal et al., 1999; Hiki et al., 2011). A smaller fraction of menthol glucuronide is also excreted in feces, and undergoes intensive enterohepatic circulation. After the cleavage of glucuronide and reabsorption in the small intestine, it is further metabolized in the liver by cytochrome P450 2A6-mediated hydroxylation and oxidation reactions (phase I reactions). p-Menthane-3,8diol and 3,8-dihydroxy-p-menthane-7-carboxylic acid have been identified as major metabolites in urine, and a fraction of these compounds is also excreted as glucuronides (Nakaoka, 1990; Miyazawa et al., 2011). Menthol metabolites are apparently pharmacologically inert, although menthol glucuronide has been investigated as a potential prodrug for oral administration (Nolen and Friend, 1994).

\section{VASCULAR ACTIONS OF MENTHOL}

Historic records about the application of menthol-containing herbs or products as therapeutic agents for cardiovascular disorders are very scarce. Menthol pharmacological properties for the cardiovascular system only became apparent in the $20^{\text {th }}$ century with the first publications appearing in the 1920s. For some decades, menthol has been known to act on the vasculature directly in the endothelium or vascular smooth muscle (VSM), with recent studies showing that it also evokes an indirect vascular response via sensory fibers. The mechanisms underlying menthol's vascular action are complex due to the diversity of cellular targets, to the interplay between signaling pathways and to the variability in terms of response. Menthol can evoke either a perfusion increase or decrease in vivo in different vascular territories, an observation that warrants a critical discussion. The next subsections present a comprehensive review of the main vascular actions attributed to menthol both in vitro and in vivo (animal models, human subjects), along with a critical discussion of the main in vivo findings to clarify these seemingly contradictory responses. Table 1 summarizes the findings of the most relevant in vivo studies to understand the actions of menthol on the vasculature. Figures 2,3 highlight the currently known mechanisms underlying both vasodilation and vasoconstriction responses observed with menthol application.

\section{Direct Action on the Vascular Wall Menthol Actions on TRPM8 Channels}

The transient receptor potential melastatin-related 8 (TRPM8) channels are widely accepted to be the main targets of menthol in different cell types, including neurons and smooth muscle cells of several organs. TRPM8 channels are also implicated in the detection of cool/cold temperatures by afferent A-delta and C nerve fibers (Kobayashi et al., 2005) and menthol activation of these channels in skin and mucosae mimics these sensations. The vascular expression of TRPM8 channels seems to differ according to animal species and age, as well as to the type of vascular bed. For example, TRPM8 were identified in rat pudendal (Silva et al., 2015), aortae, tail and mesenteric arteries (Johnson et al., 2009), while another study failed to detect their presence in the mesenteric arteries (Inoue et al., 2006). TRPM8 channels have been detected in different cellular locations, namely the plasma membrane (Gai-ying et al., 2014) and in the membrane of intracellular calcium stores, namely Golgi apparatus (Mahieu et al., 2007) and sarcoplasmic reticulum (SR) (Eccles et al., 1988; Lawrence et al., 2011; Schaefer, 2015), although there are conflicting data regarding the latter (Mahieu et al., 2007).

In the vascular endothelium, extracellular calcium influx leads to calmodulin-mediated activation of nitric oxide synthase (NOS) which increases nitric oxide (NO) synthesis, and consequently leads to VSM relaxation and vasodilation (Cohen and Vanhoutte, 1995). Calcium also opens potassium 
<smiles>CC(C)[C@H]1CC[C@@H](C)C[C@H]1O</smiles>

(+)-Menthol<smiles>CC(C)[C@H]1CC[C@@H](C)C[C@H]1O</smiles>

(+)-Neomenthol

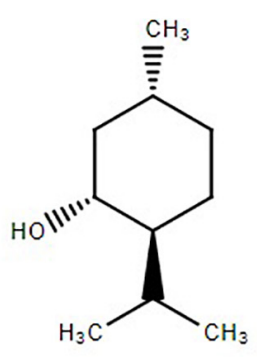

(-)-Menthol<smiles>CC(C)[C@H]1CC[C@@H](C)C[C@H]1C</smiles>

(-)-Neomenthol<smiles>CC(C)[C@H]1CC[C@@H](C)C[C@H]1O</smiles>

(+)-Isomenthol<smiles>CC(C)[C@H]1CC[C@@H](C)C[C@H]1O</smiles>

(+)-Neoisomenthol<smiles>CC(C)[C@H]1CC[C@@H](C)C[C@H]1O</smiles>

(-)-Isomenthol

FIGURE 1 | Structure of the four pairs of optical menthol isomers.

channels, leading to hyperpolarization, which is communicated to VSM cells via gap junctions with consequent relaxation and vasodilation (Félétou and Vanhoutte, 2009). In VSM, menthol induces extracellular calcium influx together with calcium release from Golgi apparatus and/or SR, both responses being mediated by TRPM8 channels (Mahieu et al., 2007; Neumann and Copello, 2011; Melanaphy et al., 2012). However, SRmediated calcium release can also be triggered independently of TRPM8 channels, although the mechanism remains unexplained (Mahieu et al., 2007). The rising cytosolic calcium concentration induces calmodulin-mediated myosin light chain kinase (MLCK) activation, which results in myosin light chain (MLC) phosphorylation and consequently in VSM contraction and vasoconstriction (Davis and Hill, 1999). This response has been demonstrated in endothelial-denuded vessels (Macpherson et al., 2006; Johnson et al., 2009; Silva et al., 2015), and observed in other smooth muscles, including the bladder (Jun et al., 2012), vas deferens (Boldyrev et al., 2009; Vladymyrova et al., 2011) and gastric fundus (Mustafa and Oriowo, 2005). It has also been proposed that TRPM8 channels might exist in cutaneous sympathetic vasodilator fibers, whereby released acetylcholine could lead to NO-dependent VSM relaxation (Johnson et al., 2009), although no studies have effectively investigated this hypothesis.

\section{Menthol Actions on Voltage-Gated Calcium Channels}

Menthol blocks L-type voltage-gated nifedipine-sensitive calcium channels in VSM cells of rat aortic, mesenteric, coronary (Cheang et al., 2013) and tail arteries (Melanaphy et al., 2016), among several other smooth muscles (Swandulla et al., 1987; Wright et al., 1997; Baylie et al., 2010; Cheang et al., 2013; Wang et al., 2016). This leads to a decrease in calcium intracellular concentration and consequently MLCK activity is overcome by that of myosin light chain phosphatase (MLCP) which leads to VSM relaxation and vasodilation.

\section{Menthol Actions on RhoA/ROCK Pathway}

There is also evidence to support that menthol causes vasodilation via suppression of the Rho-associated protein kinase (ROCK) pathway in VSM cells, presumably via TRPM8-dependent and TRPM8-independent mechanisms (Nunes et al., 2011; Xiong et al., 2017). The increase in cytosolic calcium concentration via L-type calcium channels and/or SR channels activates the RhoA/ROCK pathway. ROCK inactivates MLCP by phosphorylating its myosinbinding site, being unable to overcome MLCK activity, resulting in a sustained VSM contraction. By suppressing the RhoA/ROCK pathway, menthol increases MLCP activity, which is able to overcome MLCK activity, resulting in VSM relaxation (Fernández-Tenorio et al., 2011). Finally, menthol action on TRPM8 channels couples the release of calcium from SR stores to its uptake in the mitochondria. The increase in mitochondrial calcium uptake promotes the activity of pyruvate dehydrogenase and oxidative phosphorylation enzymes, which inhibit the production of ROS. This prevents further influx of extracellular calcium via L-type voltage-gated nifedipine-sensitive calcium channels (Xiong et al., 2017). 
TABLE 1 | Description and main results of the most relevant in vivo studies for characterizing the response of menthol in vasculature (y.o. - years old; m.o. - months old).

\begin{tabular}{|c|c|c|c|c|c|c|c|c|}
\hline Author & $\begin{array}{l}\text { Human/animal species } \\
\text { and strain (sex) }\end{array}$ & $\begin{array}{c}\text { Number and } \\
\text { mean age of } \\
\text { subjects }\end{array}$ & $\begin{array}{l}\text { Measurement } \\
\text { site }\end{array}$ & $\begin{array}{c}\text { Type of } \\
\text { application }\end{array}$ & Type of formulation & $\begin{array}{c}\text { Menthol } \\
\text { concentration }\end{array}$ & $\begin{array}{c}\text { Perfusion measurement } \\
\text { technique }\end{array}$ & $\begin{array}{l}\text { Effect on } \\
\text { perfusion }\end{array}$ \\
\hline \multicolumn{9}{|c|}{ Assessment of large caliber arteries } \\
\hline Olive et al. (2010) & Human, healthy subjects & $N=12 ; 24$ y.o. & Arm & Topical & Gel & $3.5 \%$ & $\begin{array}{l}\text { High-resolution Doppler } \\
\text { ultrasound }\end{array}$ & $\begin{array}{c}\text { Brachial artery } \\
\text { blood flow } \\
\text { decrease }\end{array}$ \\
\hline Topp et al. (2011a) & Human, healthy subjects & $N=17 ; 24$ y.o. & Forearm & Topical & Gel & $3.5 \%$ & $\begin{array}{l}\text { High-resolution Doppler } \\
\text { ultrasound }\end{array}$ & $\begin{array}{l}\text { Radial artery blood } \\
\text { flow decrease }\end{array}$ \\
\hline Topp et al. (2011b) & Human, healthy subjects & $N=16 ; 24$ y.o. & Thigh & Topical & Gel & $3.5 \%$ and $10 \%$ & $\begin{array}{l}\text { High-resolution Doppler } \\
\text { ultrasound }\end{array}$ & $\begin{array}{c}\text { Popliteal blood flow } \\
\text { and caliber } \\
\text { decrease }\end{array}$ \\
\hline Topp et al. (2013) & Human, healthy subjects & $N=19 ; 26$ y.o. & Forearm & Topical & Gel & $3.5 \%$ & $\begin{array}{l}\text { High-resolution Doppler } \\
\text { ultrasound }\end{array}$ & $\begin{array}{l}\text { Radial artery blood } \\
\text { flow decrease }\end{array}$ \\
\hline Hunter et al. (2018) & $\begin{array}{l}\text { Human, healthy subjects } \\
\text { (males) }\end{array}$ & $N=20 ; 21$ y.o. & Thigh & Topical & Ethanolic solution & $3 \%$ & $\begin{array}{l}\text { High-resolution Doppler } \\
\text { ultrasound }\end{array}$ & $\begin{array}{c}\text { Femoral blood flow } \\
\text { unchanged }\end{array}$ \\
\hline Sun et al. (2014) & $\begin{array}{c}\text { Humans, pre-hypertensive } \\
\text { subjects }\end{array}$ & $N=18 ; 57$ y.o. & Arm & Oral & Capsule & $\begin{array}{c}144 \mathrm{mg} / \text { day for } \\
8 \text { weeks }\end{array}$ & High-resolution ultrasound & $\begin{array}{c}\text { Brachial artery } \\
\text { blood flow increase }\end{array}$ \\
\hline \multicolumn{9}{|c|}{ Assessment of microcirculation - perfusion increase } \\
\hline Dölen et al. (2015) & Sprague-Dawley rats & $N=40 ; 3$ m.o. & Skin flap & Direct & Gel & $10 \%$ & Radionuclide scintigraphy & Blood flow increase \\
\hline Hong and Shellock (1991) & Human, healthy subjects & $N=10 ; 34$ y.o. & Foream & Topical & Eucalypmint & $15 \%$ & Laser Doppler flowmetry & Blood flow increase \\
\hline Wasner et al. (2004) & Human, healthy subjects & $N=10 ; 39$ y.o. & Forearm & Topical & Ethanolic solution & $40 \%$ & Laser Doppler flowmetry & Blood flow increase \\
\hline Namer et al. (2005) & Human, healthy subjects & $N=10 ; 34$ y.o. & Forearm & Topical & Ethanolic solution & $40 \%$ & Laser Doppler imaging & Blood flow increase \\
\hline Johnson et al. (2009) & Human, healthy subjects & $N=11 ; 23$ y.o. & Forearm & Topical & $\begin{array}{l}\text { Aqueous (72\%) and } \\
\text { ethanolic (25\%) solution }\end{array}$ & $3 \%$ & Laser Doppler flowmetry & Blood flow increase \\
\hline Craighead and Alexander (2016) & Human, healthy subjects & $N=10 ; 24$ y.o. & Forearm & Topical & $\begin{array}{c}\text { Alcohol and } \\
\text { water-based gel } \\
\left.\text { (Biofreeze }{ }^{\circledR}\right)\end{array}$ & $4 \%$ & $\begin{array}{l}\text { Laser speckle contrast } \\
\text { imaging }\end{array}$ & Blood flow increase \\
\hline Hunter et al. (2018) & $\begin{array}{l}\text { Human, healthy subjects } \\
\text { (males) }\end{array}$ & $N=20 ; 21$ y.o. & Thigh & Topical & Ethanolic solution & $3 \%$ & Laser Doppler flowmetry & Blood flow increase \\
\hline Craighead et al. (2017) & $\begin{array}{l}\text { Human, healthy subjects } \\
\text { (females) }\end{array}$ & $N=10 ; 23$ y.o. & Forearm & $\begin{array}{l}\text { Intradermal } \\
\text { microdialysis }\end{array}$ & $\begin{array}{l}\text { Lactated Ringer's } \\
\text { solution }\end{array}$ & $0.1-500 \mathrm{mM}$ & Laser Doppler flowmetry & Blood flow increase \\
\hline \multirow[t]{2}{*}{ Craighead et al. (2017) } & $\begin{array}{l}\text { Human, healthy and } \\
\text { subjects }\end{array}$ & $N=10 ; 50$ y.o. & Forearm & $\begin{array}{l}\text { Intradermal } \\
\text { microdialysis }\end{array}$ & $\begin{array}{l}\text { Lactated Ringer's } \\
\text { solution }\end{array}$ & $0.1-500 \mathrm{mM}$ & Laser Doppler flowmetry & Blood flow increase \\
\hline & $\begin{array}{c}\text { Human, hypertensive } \\
\text { subjects }\end{array}$ & $N=9 ; 53$ у.о. & & & & & & \\
\hline \multicolumn{9}{|c|}{ Assessment of microcirculation - perfusion decrease or unchanged } \\
\hline Yosipovitch et al. (1996) & Human, healthy subjects & $N=18 ; 47$ y.o. & Forearm & Topical & $\begin{array}{l}\text { Aqueous (10\%) and } \\
\text { ethanolic (80\%) solution }\end{array}$ & $10 \%$ & Laser Doppler flowmetry & $\begin{array}{l}\text { Blood flow } \\
\text { unchanged }\end{array}$ \\
\hline Jason Gillis et al. (2015) & Human, healthy subjects & $N=16 ; 20$ y.o. & Finger & Topical & Aqueous solution & $\begin{array}{c}0.05 \% \text { and } \\
0.2 \%\end{array}$ & Laser Doppler flowmetry & $\begin{array}{l}\text { Blood flow } \\
\text { decrease }\end{array}$ \\
\hline Valente et al. (2015) & Human, healthy subjects & $N=10 ; 24$ y.o. & Hallux & Topical & Aqueous gel & $\begin{array}{l}10 \mathrm{mg} / \mathrm{kg} \text { of } \\
\text { body weight }\end{array}$ & Laser Doppler flowmetry & $\begin{array}{l}\text { Blood flow } \\
\text { decrease }\end{array}$ \\
\hline
\end{tabular}




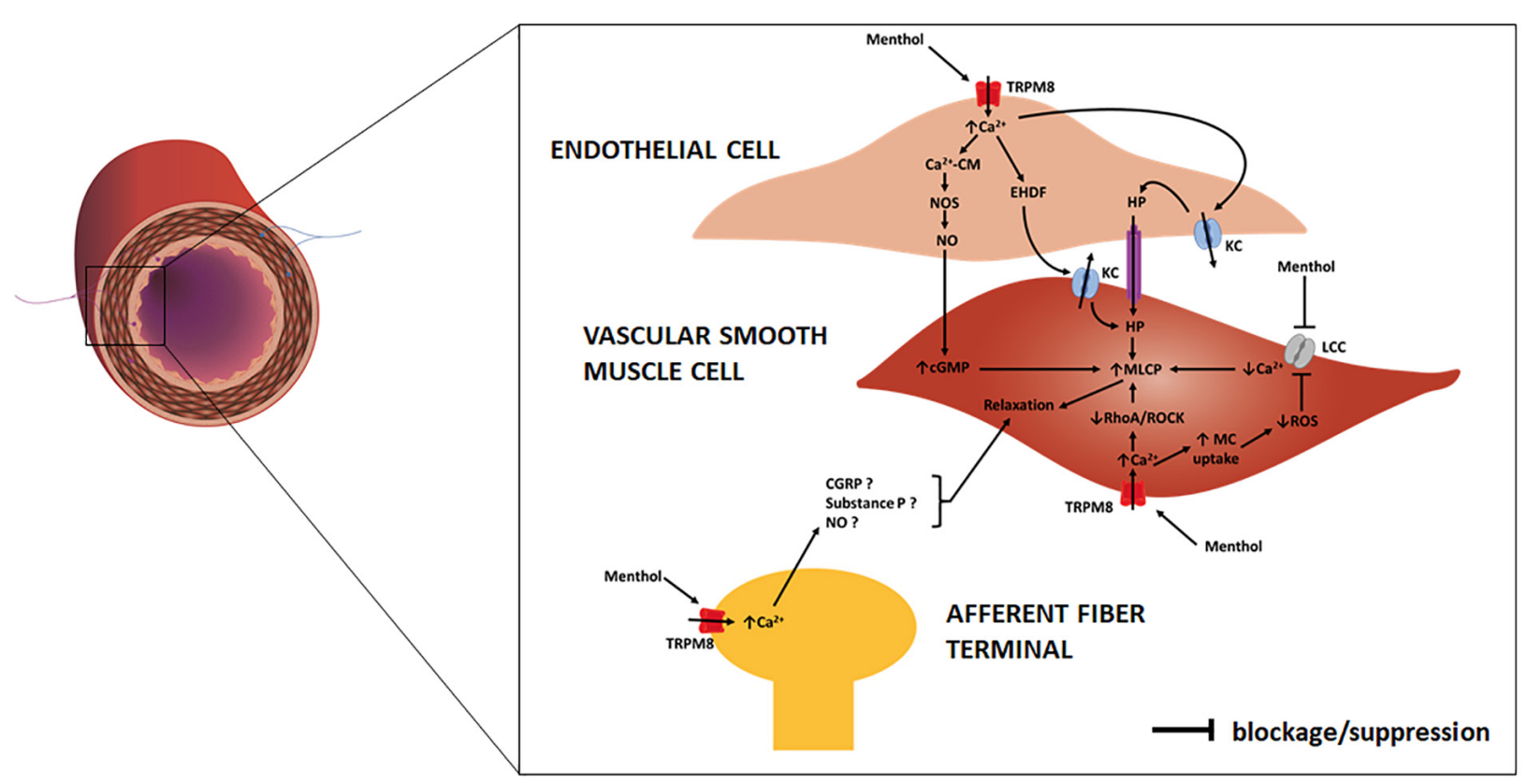

FIGURE 2 | Schematic representation of an artery/arteriole depicting its intima, media and adventitial layers. Afferent (purple) and efferent (blue) nerve fibers are included. Highlight is given to the mechanisms responsible for menthol-induced vasodilation, as proposed in previous studies. In the endothelial cell menthol activates TRPM8 channels leading to extracellular calcium influx. Increased cytosolic calcium (1) binds to calmodulin (CM) with the resulting complex activating nitric oxide synthase (NOS) which increases NO release to VSM cells, where it increases cyclic guanosine monophosphate (cGMP); (2) induces the release of endothelium derived hyperpolarization factors (EDHFs) which opens potassium channels (KC) on VSM cells; (3) induces endothelial cell potassium channels opening leading to hyperpolarization (HP), which is communicated to VSM cells. In VSM cells menthol (4) blocks membrane L-type calcium channels (LCC), decreasing extracellular calcium influx; (5) activates membrane TRPM8 channels, leading to an increase in extracellular calcium influx, which suppresses RhoA/ROCK pathway. Increased cytosolic calcium triggers mitochondrial (MC) uptake, leading to a decrease in reactive oxygen species (ROS) production, which prevents opening of LCC. Increased cGMP, decreased cytosolic calcium concentration and suppressed RhoA/ROCK pathway contribute to an increase of myosin light chain phosphatase (MLCP) activity and VSM cell relaxation. On afferent A-delta and C fibers menthol may activate TRPM8 channels leading to an increased cytosolic calcium concentration and to the release of several substances, possibly calcitonin gene-related peptide (CGRP), substance P and NO, which lead to VSM cell relaxation.

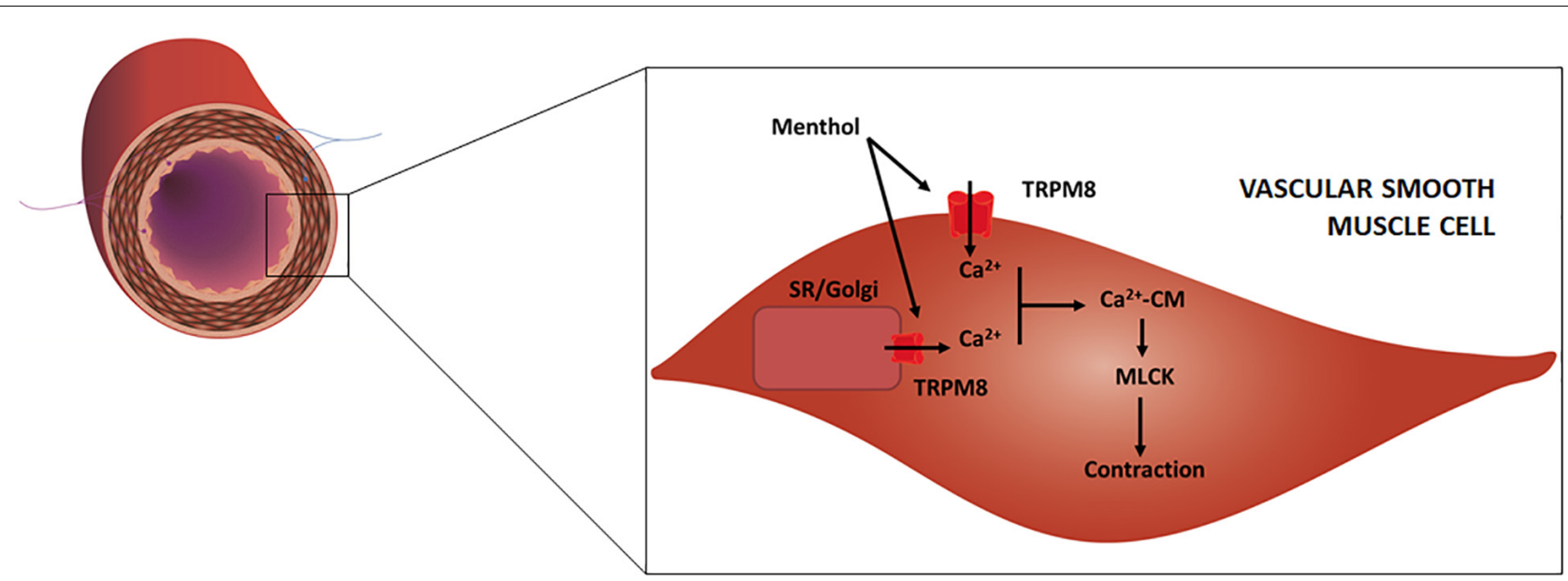

FIGURE 3 | Schematic representation of an artery/arteriole depicting its intima, media and adventitial layers. Afferent (purple) and efferent (blue) nerve fibers are included. Highlight is given to the mechanisms responsible for menthol-induced vasoconstriction, as proposed in previous studies. Menthol activates TRPM8 channels located on (1) plasma membrane, leading to extracellular calcium influx, and (2) on the sarcoplasmic reticulum (SR) and/or Golgi apparatus leading to calcium release. Increased cytosolic calcium binds to calmodulin (CM) and the resulting complex activates myosin light chain kinase (MLCK) which leads to VSM contraction. 


\section{Menthol Actions on TRPA1 Channels}

Transient receptor potential ankyrin transmembrane protein 1 (TRPA1) channels have been identified on endothelial cells of rat arteries (Earley et al., 2009; Pozsgai et al., 2010), more concentrated in the myoendothelial junction (Earley, 2012). Activation of endothelial TRPA1 channels leads to cell hyperpolarization which is communicated to VSM cells via gap junctions, with consequent VSM relaxation and vasodilation (Earley et al., 2009). Activation of VSM cell TRPA1 leads to RhoA/ROCK pathway activation and vasoconstriction (Aubdool et al., 2014). TRPA1 channels are also found in adventitial nerve fibers (Bautista et al., 2005). Afferent fibers TRPA1 channel activation detects local cooling together with TRPM8 channels (Pan et al., 2018) and can induce the release of CGRP, substance $\mathrm{P}$ and NO (Aubdool et al., 2014, 2016). Efferent sympathetic TRPA1 channel activation induces release of noradrenaline to VSM adrenergic receptors (Aubdool et al., 2014). Menthol actions on TRPA1 channels have striking differences according to species. While non-mammalian TRPA1 channels are insensitive to menthol (Xiao et al., 2008), mammalian TRPA1 respond differently depending on the concentration, showing a bimodal response. In mammalian cell cultures low $(\sim 50-70 \mu \mathrm{M})$ menthol concentrations activate TRPA1 channels (Karashima et al., 2007), while high concentrations $(\geq 250 \mathrm{mM}$ ) inhibit them (Macpherson et al., 2006; Karashima et al., 2007). In human TRPA1 channels, menthol only acts as an activator (Xiao et al., 2008). To date no studies reporting any action of menthol in vascular TRPA1 channels exist.

\section{Menthol Actions on TRPV Channels}

Transient receptor potential vanilloid-receptor-related (TRPV) channels 1-4 have been identified in murine and rat arteries and nerves (Earley and Brayden, 2015; Du et al., 2019). TRPV3 and TRPV4 are expressed both in endothelial and VSM cells, TRPV1 in endothelial cells and sensory nerve fibers, while TRPV2 were found only in VSM cells (Earley and Brayden, 2015). Activation of these receptors leads to vasodilation through NOdependent, NO-independent, sensory-mediated mechanisms. To date, however, menthol has only been found to activate neuronal TRPV3 channels (Macpherson et al., 2006) and to block TRPV1 channels in cell cultures (Takaishi et al., 2016). Since there are no studies reporting a vascular action in these receptors, it is presently unclear whether any menthol vascular effect is attributed to its action on TRPV channels.

\section{Interaction of Ethanol on Menthol Receptors}

Ethanol is commonly used as a solvent in several mentholbased formulations given the latter's low water solubility. It is also known to interfere with the activity of both TRPM8 and TRPV1 channels. TRPM8 channel activation is dependent on the presence of membrane lipid phosphatidylinositol-4,5biphosphate $\left(\mathrm{PIP}_{2}\right)$ insofar as its removal by phospholipase enzyme isoforms contributes to this channel's desensitization (Benedikt et al., 2007). Ethanol can diminish the TRPM8 response to menthol by weakening its interaction with $\mathrm{PIP}_{2}$ (Weil et al., 2005; Benedikt et al., 2007). Therefore, it is possible that ethanol-based menthol formulations may weaken menthol response both at the endothelium and VSM cells. TRPV1 channels are inhibited by $\mathrm{PIP}_{2}$, therefore ethanol can potentiate their response to menthol (Benedikt et al., 2007). Whether ethanol also interferes with the binding of menthol to TRPV1 channels is currently unknown.

Ethanol is itself a vasoactive substance, being able to induce either vasodilation or vasoconstriction in different vascular beds. Its best known effect is vascular relaxation, a response typically found in pulmonary (Greenberg et al., 1993), mesenteric (Ru et al., 2008), cutaneous (Altura and Altura, 1982, 1987) and cerebral blood vessels (Altura and Altura, 1999), which has been attributed to the potentiation of NO-dependent and NO-independent vasodilation pathways (Rocha et al., 2012; Tawakol et al., 2019). In certain vascular beds ethanol-induced vasodilation is rather attributed to its metabolite acetaldehyde, which mediates an endothelium-dependent relaxation (Jin et al., 2019) in mesenteric vessels. Furthermore, acetate, a metabolite of aldehyde also displays a moderate vasodilator response (Altura and Altura, 1982). In contrast, some vascular beds tend to be constricted by ethanol, such as the cerebral (Altura and Altura, 1982, 1987), coronary (Altura et al., 1983), mesenteric (Toda et al., 1983; Ru et al., 2008), aortic (Ru et al., 2008), an effect that may involve extra-endothelial TRPV1 channels (Cleland et al., 2019). Ethanol could interfere with the vascular action of menthol via direct and/or indirect mechanisms both in vitro and in vivo. It could be acting directly on the vascular wall, as well as indirectly by modulating the binding of menthol to TRPM8 and TRPV1 receptors. Either way, it is critical that experimental settings involving menthol administration in ethanol-based formulations address its intrinsic vascular effects (see Table 1).

\section{Menthol-Induced Vasoconstriction}

In several in vivo studies carried out to date menthol has not been applied directly to the vessels via parenteral routes, but on the skin, either topically or via intradermal microdialysis. Perfusion has been assessed at the application site or at deeper/distant sites relative to the application site. In addition, a few studies have also explored the effects of orally administered menthol. An important observation has been made - large caliber arteries respond mainly to menthol application with perfusion decrease while cutaneous microcirculation responds mainly with perfusion increase.

Perfusion decrease has been consistently described in the brachial (Olive et al., 2010) and radial (Topp et al., 2011a, 2013) arteries after topical application on the forearm, and in the popliteal arteries (Topp et al., 2011b) after application on the thigh. In both cases, perfusion was assessed with highresolution Doppler ultrasound, and decreased both ipsilateral and contralateral to the side of application (popliteal). Although this perfusion decrease is likely attributed to vascular caliber reduction, this was only observed in one study (Topp et al., 2011b), which can be attributed to the technique's limited sensitivity (Topp et al., 2013). At first glance, these results suggest that menthol undergoes transdermal absorption, reaches systemic circulation and causes the constriction of these 
territories. In fact, one study reported that following application in dermal patches menthol reached systemic circulation in low but detectable levels (Martin et al., 2004). Although such low doses are unlikely to cause an observable effect, this cannot be discarded as the authors did not measure perfusion in areas far from the application site.

Another hypothesis is that perfusion decrease may be attributed to a decrease in tissue/organ temperature, not in response to menthol but rather to the ethanol contained in the formulation. In recent studies, topical menthol application caused a decrease in muscle (Hunter et al., 2018) and skin temperature (Lasanen et al., 2016), irrespective of concentration. In both cases this response was not attributed to a possible menthol action on the vasculature (not measured) but rather to an increase in evaporative heat loss caused by ethanol (Hunter et al., 2018), which may have directly caused vessel constriction. This again suggests that menthol permeation of muscle from topical application is not likely to occur. Again, it is also possible that ethanol interfered with TRPM8 channels, decreasing menthol activity, a hypothesis that needs further investigation.

A third hypothesis is that menthol may evoke neural-mediated thermoregulatory responses. It is possible that menthol action on TRPM8 and TRPA1 channels present in sensory A-delta and cold-sensory C fibers (Mahieu et al., 2007; Dhaka et al., 2008) can trigger a sympathetic-mediated heat-conservation constriction of large-caliber arteries (Pan et al., 2018). Evidence for the existence of menthol-evoked heat-conservation responses comes from studies reporting that menthol lowers temperature thresholds for virtually all the thermoregulatory responses to cooling (Kozyreva et al., 2010), which are attributed to TRPM8 channel activation (Camila Almeida et al., 2012). In humans, application of a menthol spray on the upper body results in a vasoconstriction response on finger microcirculation (Jason Gillis et al., 2015). Furthermore, whole-body application results in a slower decrease of rectal temperature comparing with cool water immersion, which was again attributed to peripheral vasoconstriction (Kounalakis et al., 2010) even though perfusion was not assessed. Similar results were found with the application of menthol on the trunk of mice (Tajino et al., 2019) and with the immersion of the upper extremities in cold water, in which menthol attenuated cold-induced restorative vasodilation (perfusion not assessed) (Kim and Lee, 2018). Taken together, these results suggest that application of menthol over a moderate/large skin surface initiates heat-conservation responses caused by cold perception. It is likely that cold perception could have resulted in the sympathetic-mediated decrease in the caliber of large blood vessels (Guimarães and Moura, 2001) deep to the application sites and on the microcirculation of nonprovoked skin. This should be further investigated by assessing the caliber of the cutaneous branches of deep arteries during menthol application.

\section{Menthol-Induced Vasodilation}

The microcirculation response to topically applied menthol seems to depend on whether the assessed skin region was directly provoked with menthol or not. In non-provoked skin menthol is reported to induce cutaneous temperature/perfusion decrease. Menthol gels $(0.5,4.6,10 \%)$ cause skin temperature reduction irrespectively of concentration (Lasanen et al., 2016), which may be explained by an increase in evaporative heat loss induced by the formulation ethanol (10\%). A similar explanation seems to match the observed decrease in skin microcirculatory perfusion after spraying menthol $(0.05,0.2 \%)$ on the torso and upper limbs (Jason Gillis et al., 2015). Similarly, the application of menthol (10 mg/kg of body weight) on the neck, arm and leg evokes perfusion reduction on the hallux (Valente et al., 2015). However, in this study perfusion was assessed during lower limb dependency (sitting), which is likely to have evoked the venoarteriolar reflex, further contributing to the observed perfusion decrease (Crandall et al., 2002).

In the majority of studies assessing provoked skin, menthol has been found to increase microcirculatory perfusion, either by topical application (Crandall et al., 2002; Wasner et al., 2004; Kobayashi et al., 2005; Topp et al., 2013; Craighead and Alexander, 2016; Kim and Lee, 2018) or intradermal microdialysis (Hong and Shellock, 1991; Guimarães and Moura, 2001). When topically applied, menthol passively diffuses through the epidermis and reaches the dermal microvascular networks. Even assuming that heat-conservation sympathetic vasoconstrictive reflex may occur in the provoked region, it is probably being offset by menthol-mediated vasodilation (Charkoudian and Clinic, 2010). To date only one study showed that topical application did not affect perfusion of the provoked region (Yosipovitch et al., 1996). In this study, menthol was applied in a highly concentrated (80\%) ethanol solution, therefore raising the question whether ethanol-induced menthol evaporation may have occurred before any response could be measured. In addition, it is also reasonable to assume that the short application and recording periods may have thwarted the observation of any vascular response. When administered via intradermal microdialysis, menthol is directly delivered to the dermal microvascular networks, therefore reducing the contribution of heat-conservation responses initiated by cold perception in the epidermal sensory fibers. Studies that investigated the vascular response with this technique also benefited from the use of lactated Ringer's solution as a solvent instead of ethanol (Craighead and Alexander, 2017; Craighead et al., 2017). In these conditions, menthol consistently induced perfusion increase, which is dose-dependent and results from the interplay of sensory, NO-dependent and NO-independent (EDHFs) mechanisms (Craighead et al., 2017).

Currently, several mechanisms are known to contribute to menthol-induced vasodilation: (1) endothelial TRPM8 activation leading to an increase in NO release (endothelial NO-dependent response); (2) VSM L-type voltage-gated calcium channel blockade; (3) RhoA/ROCK pathway suppression. Several other mechanisms have been proposed to contribute to this response, although they need to be experimentally tested. For example, menthol co-activation of TRPA1 and TRPV channels in sensory afferent fibers, endothelial and/or VSM cells have been proposed (Craighead et al., 2017), even though no studies have reported that menthol binds these receptors in vascular cells. Menthol may 
induce vasodilation via generation of heat-gain responses that more specifically target brown adipose tissue and perivascular adipose tissue, which are sources of heat and adipose-derived relaxing factors, respectively (Gollasch, 2012). These tissues are known to express TRPM8 channels and to initiate thermogenesis in response to cold and menthol activation (Ma et al., 2012). Interestingly, recent studies report that increased thermogenic activity of perivascular adipose tissue has been associated with improved endothelial function and protection from vascular disease (Chang et al., 2012, 2013).

\section{Anti-Hypertensive Effects of Menthol}

Parenteral and oral routes have also suggested a considerable BP lowering capacity for menthol. The anti-hypertensive potential of menthol was first recognized by Rakieten in 1957 with the intravenous administration to lower BP in cats and rabbits (Rakieten, 1957). When administered orally, the effects of menthol are dependent on the dose and duration of exposure. In healthy humans, a single oral administration of $100 \mathrm{mg}$ of menthol is reported not to influence BP (Gelal et al., 1999) and therefore does not seem to evoke a vascular response. A higher dose (10 mg/kg of body weight), however, does evoke a cutaneous perfusion reduction (BP not measured) (Valente et al., 2015). In contrast, prolonged oral supplementation lowers blood pressure in hypertensive rodents (Sun et al., 2014; Xiong et al., 2017) and in prehypertensive humans. In the latter it also increases flow-mediated vasodilation (Sun et al., 2014), suggesting an improvement in endothelial function (Roustit et al., 2016). These effects are partly explained by the suppression of the RhoA/ROCK pathway by menthol, which was found to increase in human (primary and environmentally-induced) and experimentallyinduced hypertension (Nunes et al., 2011; Xiong et al., 2017). Several other cellular targets of menthol are also implicated in hypertension. For example, a recent study suggests that angiotensin II induces VSM TRPM8 channel down-regulation in renovascular hypertension (Huang et al., 2017) and in pulmonary

\section{REFERENCES}

Altura, B. M., and Altura, B. T. (1982). Microvascular and vascular smooth muscle actions of ethanol, acetaldehyde, and acetate. Fed. Proc. 41, 2447-2451.

Altura, B. M., and Altura, B. T. (1987). Peripheral and cerebrovascular actions of ethanol, acetaldehyde, and acetate: relationship to divalent cations. Clin. Exp. Res. 11, 99-111. doi: 10.1111/j.1530-0277.1987.tb01272.x

Altura, B. M., and Altura, B. T. (1999). Association of alcohol in brain injury, headaches, and stroke with brain-tissue and serum levels of ionized magnesium: a review of recent findings and mechanisms of action. Alcohol 19, 119-130. doi: 10.1016/s0741-8329(99)00025-7

Altura, B. M., Altura, B. T., and Carella, A. (1983). Ethanol produces coronary vasospasm: evidence for a direct action of ethanol on vascular muscle. $\mathrm{Br}$. J. Pharmacol. 78, 260-262. doi: 10.1111/j.1476-5381.1983.tb09389.x

Aubdool, A. A., Graepel, R., Kodji, X., Alawi, K. M., Bodkin, J. V., Srivastava, S., et al. (2014). TRPA1 is essential for the vascular response to environmental cold exposure. Nat. Commun. 5:5732. doi: 10.1038/ncomms6732

Aubdool, A. A., Kodji, X., Abdul-Kader, N., Heads, R., Fernandes, E. S., Bevan, S., et al. (2016). TRPA1 activation leads to neurogenic vasodilatation: involvement of reactive oxygen nitrogen species in addition to CGRP and NO. Br. J. Pharmacol. 173, 2419-2433. doi: 10.1111/bph.13519 hypertension (Liu et al., 2013). Therefore, it is logical that the activation of TRPM8 channels by menthol can also contribute to this blood pressure lowering response.

\section{CONCLUSION}

Menthol is a versatile molecule with complex actions on the vasculature which remain far from clear. Several cellular targets have been identified in both endothelial and VSM cells as well as in afferent nerve fibers involving a crosstalk between multiple signaling pathways. Menthol is known to activate TRPM8 channels in the endothelium, VSM and vascular afferent nerve fibers, while also blocking VSM L-type calcium channels. Several other menthol targets have been identified in nonvascular tissues including TRPA1, TRPV1 and TRPV 3 channels, but whether menthol also acts on vasculature via these channels is still undetermined. Menthol vascular action in vivo seems to depend on whether the vascular territory under analysis has been directly provoked with menthol or is located deep/distant to the application site. Menthol increases perfusion of directly provoked skin regions due to a complex interplay of increased $\mathrm{NO}, \mathrm{EDHF}$ and sensory nerve responses. In non-provoked vascular beds menthol induces vasoconstriction which might be attributed to heat-conservation sympathetically-mediated vasoconstriction, although an increase in tissue evaporative heat loss due the formulation ethanol may also play a role. There is increasing evidence that several of menthol's cellular targets are involved in cardiovascular diseases, such as hypertension. Thus menthol and pharmacologically-similar drugs can play important preventive and therapeutic roles, which merits further investigation.

\section{AUTHOR CONTRIBUTIONS}

HS contributed literature research and manuscript editing.

Bautista, D. M., Movahed, P., Hinman, A., Axelsson, H. E., Sterner, O., Högestätt, E. D., et al. (2005). Pungent products from garlic activate the sensory ion channel TRPA1. Proc. Natl. Acad. Sci. U.S.A. 102, 12248-12252. doi: 10.1073/ pnas.0505356102

Baylie, R. L., Cheng, H., Langton, P. D., and James, A. F. (2010). Inhibition of the cardiac l-type calcium channel current by the TRPM8 agonist, (-)-menthol. J. Physiol. Pharmacol. 61, 543-550.

Benedikt, J., Teisinger, J., Vyklicky, L., and Vlachova, V. (2007). Ethanol inhibits cold-menthol receptor TRPM8 by modulating its interaction with membrane phosphatidylinositol 4,5-bisphosphate. J. Neurochem. 100, 211-224. doi: 10. 1111/j.1471-4159.2006.04192.x

Bhatia, S. P., McGinty, D., Letizia, C. S., and Api, A. M. (2008). Fragrance material review on d-menthol. Food Chem. Toxicol. 46(Suppl. 11), 215-217. doi: 10. 1016/j.fct.2008.06.039

Boldyrev, O. I., Sotkis, H. V., Kuliieva, I. M., Vladymyrova, I. A., Filippov, I. B., Skryma, R., et al. (2009). Expression of the cold receptor TRPM8 in the smooth muscles of the seminal ejaculatory ducts in rats. Fiziol. Zh. 55, 17-27.

Camila Almeida, M., Hew-Butler, T., Soriano, R. N., Rao, S., Wang, W., Wang, J., et al. (2012). Pharmacological blockade of the cold receptor TRPM8 attenuates autonomic and behavioral cold defenses and decreases deep body temperature. J. Neurosci. 32, 2086-2099. doi: 10.1523/JNEUROSCI.5606-11.2012 
Chang, L., Milton, H., Eitzman, D. T., and Chen, Y. E. (2013). Paradoxical roles of perivascular adipose tissue in atherosclerosis and hypertension. Circ. J. 77, 11-18. doi: 10.1253/circj.cj-12-1393

Chang, L., Villacorta, L., Li, R., Hamblin, M., Xu, W., Dou, C., et al. (2012). Loss of perivascular adipose tissue upon PPAR $\gamma$ deletion in smooth muscle cells impairs intravascular thermoregulation and enhances atherosclerosis. Circulation 126, 1067-1078. doi: 10.1161/circulationaha.112.10 4489

Charkoudian, N., and Clinic, M. (2010). Mechanisms and modifiers of reflex induced cutaneous vasodilation and vasoconstriction in humans. J. Appl. Physiol. 109, 1221-1228. doi: 10.1152/japplphysiol.00298.2010

Cheang, W. S., Lam, M. Y., Wong, W. T., Tian, X. Y., Lau, C. W., Zhu, Z., et al. (2013). Menthol relaxes rat aortae, mesenteric and coronary arteries by inhibiting calcium influx. Eur. J. Pharmacol. 702, 79-84. doi: 10.1016/j.ejphar. 2013.01.028

Cleland, K., Chang, J., Bukiya, A. N., and Dopico, A. M. (2019). Extra-endothelial TRPV1 channels participate in alcohol and caffeine actions on cerebral artery diameter. Alcohol 73, 45-55. doi: 10.1016/j.alcohol.2018.04.002

Cohen, R. A., and Vanhoutte, P. M. (1995). Endothelium-dependent hyperpolarization. Circulation 92, 3337-3349.

Craighead, D. H., and Alexander, L. M. (2016). Topical menthol increases cutaneous blood flow. Microvasc. Res. 107, 39-45. doi: 10.1016/j.mvr.2016.0 4.010

Craighead, D. H., and Alexander, L. M. (2017). Menthol-induced cutaneous vasodilation is preserved in essential hypertensive men and women. Am. J. Hypertens. 30, 1156-1162. doi: 10.1093/ajh/hpx127

Craighead, D. H., McCartney, N. B., Tumlinson, J. H., and Alexander, L. M. (2017). Mechanisms and time course of menthol-induced cutaneous vasodilation. Microvasc. Res. 110, 43-47. doi: 10.1016/j.mvr.2016.11.008

Crandall, C. G., Shibasaki, M., and Yen, T. C. (2002). Evidence that the human cutaneous venoarteriolar response is not mediated by adrenergic mechanisms. J. Physiol. 538, 599-605. doi: 10.1113/jphysiol.2001.013060

Davis, M. J., and Hill, M. A. (1999). Signaling mechanisms underlying the vascular myogenic response. Physiol. Rev. 79, 387-423. doi: 10.1152/physrev.1999.79. 2.387

Dhaka, A., Earley, T. J., Watson, J., and Patapoutian, A. (2008). Visualizing cold spots: TRPM8-expressing sensory neurons and their projections. J. Neurosci. 28, 566-575. doi: 10.1523/JNEUROSCI.3976-07.2008

Dölen, U. C., Sungur, N., Koca, G., Ertunç, O., Bosi, A. T. B., Koçer, U., et al. (2015). The vasodilator effect of a cream containing $10 \%$ menthol and $15 \%$ methyl salicylate on random-pattern skin flaps in rats. Arch. Plast. Surg. 42, 695-703. doi: 10.5999/aps.2015.42.6.695

Du, Q., Liao, Q., Chen, C., Yang, X., Xie, R., and Xu, J. (2019). The role of transient receptor potential vanilloid 1 in common diseases of the digestive tract and the cardiovascular and respiratory system. Front. Physiol. 10:1064. doi: $10.3389 /$ fphys.2019.01064

Earley, S. (2012). TRPA1 channels in the vasculature. Br. J. Pharmacol. 167, 13-22. doi: 10.1111/j.1476-5381.2012.02018.x

Earley, S., and Brayden, J. E. (2015). Transient receptor potential channels in the vasculature. Physiol. Rev. 95, 645-690. doi: 10.1152/physrev.00026.2014

Earley, S., Gonzales, A. L., and Crnich, R. (2009). Endothelium-dependent cerebral artery dilation mediated by TRPA1 and $\mathrm{Ca} 2+$-activated $\mathrm{K}+$ channels. Circ. Res. 104, 987-994. doi: 10.1161/CIRCRESAHA.108.189530

Eccles, R. (1994). Menthol and related cooling compounds. J. Pharm. Pharmacol. 46, 618-630. doi: 10.1111/j.2042-7158.1994.tb03871.x

Eccles, R., Griffiths, D. H., Newton, C. G., and Tolley, N. S. (1988). The effects of menthol isomers on nasal sensation of airflow. Clin. Otolaryngol. Allied Sci. 13, 25-29. doi: 10.1111/j.1365-2273.1988.tb00277.x

Félétou, M., and Vanhoutte, P. M. (2009). EDHF: an update. Clin. Sci. 117, 139-155. doi: 10.1042/CS20090096

Fernández-Tenorio, M., Porras-González, C., Castellano, A., Del Valle-Rodríguez, A., López-Barneo, J., and Ureña, J. (2011). Metabotropic regulation of RhoA/Rho-associated kinase by l-type Ca2+ channels: new mechanism for depolarization-evoked mammalian arterial contraction. Circ. Res. 108, 13481357. doi: 10.1161/CIRCRESAHA.111.240127

Gai-ying, C., Hai-xia, J., Ming-yue, W., Rui-xing, W., and Mo-jun, L. I. N. (2014). Decreased amplitude of [Ca2+]I elevation induced by menthol in pulmonary arterial smooth muscle cells of pulmonary hypertensive rats. Acta Physiol. Sin. $66,267-275$.
Gelal, A., Jacob, P. III, Yu, L., Benowitz, N. L., and Francisco, S. (1999). Disposition kinetics and effects of menthol. Clin. Pharmacol. Ther. 66, 128-135. doi: 10 1053/cp.1999.v66.100455001

Gollasch, M. (2012). Vasodilator signals from perivascular adipose tissue. Br. J. Pharmacol. 165, 633-642. doi: 10.1111/j.1476-5381.2011.01430.x

Greenberg, S. S., Xie, J., Wang, Y., Kolls, J., Shellito, J., Nelson, S., et al. (1993). Ethanol relaxes pulmonary artery by release of prostaglandin and nitric oxide. Alcohol 10, 21-29. doi: 10.1016/0741-8329(93)90049-t

Guimarães, S., and Moura, D. (2001). Vascular adrenoceptors: an update. Pharmacol. Rev. 53, 319-356.

Hiki, N., Kaminishi, M., Hasunuma, T., Nakamura, M., Nomura, S., Yahagi, N., et al. (2011). A phase I study evaluating tolerability, pharmacokinetics, and preliminary efficacy of 1-menthol in upper gastrointestinal endoscopy. Clin. Pharmacol. Ther. 90, 221-228. doi: 10.1038/clpt.2011.110

Hong, C., and Shellock, F. (1991). Effects of a topically applied counterirritant (Eucalyptamint) on cutaneous blood flow and on skin and muscle temperatures. A placebo-controlled study. Am. J. Phys. Med. Rehabil. 70, 29-33. doi: 10.1097/ 00002060-199102000-00006

Huang, F., Ni, M., Zhang, J. M., Li, D. J., and Shen, F. M. (2017). TRPM8 downregulation by angiotensin II in vascular smooth muscle cells is involved in hypertension. Mol. Med. Rep. 15, 1900-1908. doi: 10.3892/mmr.2017.6158

Hunter, A. M., Grigson, C., and Wade, A. (2018). Influence of topically applied menthol cooling gel on soft tissue thermodynamics and arterial and cutaneous blood flow at rest. Int. J. Sports Phys. Ther. 13, 483-492. doi: 10.26603/ ijspt20180483

Inoue, R., Jensen, L. J., Shi, J., Morita, H., Nishida, M., Honda, A., et al. (2006). Transient receptor potential channels in cardiovascular function and disease. Circ. Res. 99, 119-131. doi: 10.1161/01.res.0000233356.10630.8a

Jason Gillis, D., Weston, N., House, J. R., and Tipton, M. J. (2015). Influence of repeated daily menthol exposure on human temperature regulation and perception. Physiol. Behav. 139, 511-518. doi: 10.1016/j.physbeh.2014.12.009

Jin, L., Lorkiewicz, P., Malovichko, M. V., Bhatnagar, A., Srivastava, S., and Conklin, D. J. (2019). Acetaldehyde induces an endothelium-dependent relaxation of superior mesenteric artery: potential role in postprandial hyperemia. Front. Physiol. 10:1315. doi: 10.3389/fphys.2019.01315

Johnson, C. D., Melanaphy, D., Purse, A., Stokesberry, S. A., Dickson, P. and Zholos, A. V. (2009). Transient receptor potential melastatin 8 channel involvement in the regulation of vascular tone. Am. J. Physiol. Heart Circ. Physiol. 296, H1868-H1877. doi: 10.1152/ajpheart.01112.2008

Jun, J. H., Kang, H. J., Jin, M. H., Lee, H. Y., Im, Y. J., Jung, H. J., et al. (2012). Function of the cold receptor (TRPM8) associated with voiding dysfunction in bladder outlet obstruction in rats. Int. Neurourol. J. 16, 69-76. doi: 10.5213/inj. 2012.16.2.69

Kamatou, G. P. P., Vermaak, I., Viljoen, A. M., and Lawrence, B. M. (2013). Menthol: a simple monoterpene with remarkable biological properties. Phytochemistry 96, 15-25. doi: 10.1016/j.phytochem.2013.08.005

Karashima, Y., Damann, N., Prenen, J., Talavera, K., Segal, A., Voets, T., et al. (2007). Bimodal action of menthol on the transient receptor potential channel TRPA1. J. Neurosci. 27, 9874-9884. doi: 10.1523/jneurosci.2221-07.2007

Kim, S., and Lee, J. Y. (2018). L-Menthol attenuates the magnitude of cold-induced vasodilation on the extremities of young females. J. Physiol. Anthropol. 37:14. doi: 10.1186/s40101-018-0174-x

Kobayashi, K., Fukuoka, T., Obata, K., Yamanaka, H., Dai, Y., Tokunaga, A., et al. (2005). Distinct expression of TRPM8, TRPA1, and TRPV1 mRNAs in rat primary afferent neurons with $\mathrm{A} \delta / \mathrm{C}$-fibers and colocalization with Trk receptors. J. Comp. Neurol. 493, 596-606. doi: 10.1002/cne.20794

Kounalakis, S. N., Academy, H. A., Botonis, P. G., Koskolou, M., and Geladas, N. (2010). The effect of menthol application to the skin on sweating rate response during exercise in swimmers and controls the effect of menthol application to the skin on sweating rate response during exercise in swimmers and controls. Eur. J. Appl. Physiol. 209, 183-189. doi: 10.1007/s00421-0091345-6

Kozyreva, T. V., Kozaruk, V. P., Tkachenko, E. Y., and Khramova, G. M. (2010). Agonist of TRPM8 channel, menthol, facilitates the initiation of thermoregulatory responses to external cooling. J. Therm. Biol. 35, 428-434. doi: 10.1016/j.jtherbio.2010.09.004

Lasanen, R., Julkunen, P., and Airaksinen, O. (2016). Menthol concentration in topical cold gel does not have significant effect on skin cooling. Skin Res. Technol. 22, 40-45. doi: 10.1111/srt.12226 
Lawrence, B. M. (ed.). (2006). Mint - The Genus Mentha. Boca Raton, FL: CRC Press.

Lawrence, D., Cadman, B., and Hoffman, A. C. (2011). Sensory properties of menthol and smoking topography. Tob. Induc. Dis. 9(Suppl. 1):S3. doi: 10.1186/ 1617-9625-9-S1-S3

Liu, X.-R., Liu, Q., Chen, G.-Y., Hu, Y., Sham, J. S. K., and Lina, M.-J. (2013). Downregulation of TRPM8 in pulmonary arteries of pulmonary hypertensive rats. Cell. Physiol. Biochem. 31, 892-904. doi: 10.1159/000350107

Ma, S., Yu, H., Zhao, Z., Luo, Z., Chen, J., Ni, Y., et al. (2012). Activation of the cold-sensing TRPM 8 channel triggers UCP 1 -dependent thermogenesis and prevents obesity. J. Mol. Cell Biol. 4, 88-96. doi: 10.1093/jmcb/mjs001

Macpherson, L. J., Hwang, S. W., Miyamoto, T., Dubin, A. E., Patapoutian, A., and Story, G. M. (2006). More than cool: promiscuous relationships of menthol and other sensory compounds. Mol. Cell. Neurosci. 32, 335-343. doi: 10.1016/j.mcn. 2006.05.005

Mahieu, F., Owsianik, G., Verbert, L., Janssens, A., De Smedt, H., Nilius, B., et al. (2007). TRPM8-independent menthol-induced $\mathrm{Ca} 2+$ release from endoplasmic reticulum and Golgi. J. Biol. Chem. 282, 3325-3336. doi: 10.1074/ jbc.m605213200

Martin, D., Valdez, J., Boren, J., and Mayersohn, M. (2004). Dermal absorption of camphor, menthol, and methyl salicylate in humans. J. Clin. Pharmacol. 44, 1151-1157. doi: 10.1177/0091270004268409

Melanaphy, D., Borysova, L., Kustov, M., Watson, C., Johnson, C., Burdyga, T., et al. (2012). Molecular expression and calcium signalling roles of native TRP channels in vascular cells. Cell. Membr. Free Radic Res. 4, 195-201.

Melanaphy, D., Johnson, C. D., Kustov, M. V., Watson, C. A., Borysova, L., Burdyga, T. V., et al. (2016). Ion channel mechanisms of rat tail artery contraction-relaxation by menthol involving, respectively, TRPM8 activation and L-type Ca $2 \zeta$ channel inhibition. Am J Physiol. Circ. Physiol. 311, H1416H1430. doi: 10.1152/ajpheart.00222.2015

Miyazawa, M., Marumoto, S., Takahashi, T., Nakahashi, H., Haigou, R., and Nakanishi, K. (2011). Metabolism of (+)- and (-)-menthols by CYP2A6 in human liver microsomes. J. Oleo Sci. 60, 127-132. doi: 10.5650/jos.6 0.127

Mustafa, S., and Oriowo, M. A. (2005). Cooling-induced contraction of the rat gastric fundus: mediation via transient receptor potential (TRP) cation channel TRPM8 receptor and Rho-kinase activation. Clin. Exp. Pharmacol. Physiol. 32, 832-838. doi: 10.1111/j.1440-1681.2005.04273.x

Nakaoka, M. (1990). Kinetic characteristics of UDP-glucuronyl transferases toward a dithiol metabolite of malotilate in hepatic microsomes of rats and rabbits. Xenobiotica 20, 619-628.

Namer, B., Seifert, F., Handwerker, H. O., and Maih, C. (2005). TRPA1 and TRPM8 activation in humans: effects of cinnamaldehyde and menthol. Neuroreport 16 , 955-959. doi: 10.1097/00001756-200506210-00015

Neumann, J. T., and Copello, J. A. (2011). Cross-reactivity of ryanodine receptors with plasma membrane ion channel modulators. Mol. Pharmacol. 80, 509-517. doi: $10.1124 / \mathrm{mol} .111 .071167$

Nolen, H. W. III and Friend, D. (1994). Menthol-beta-D-glucuronide: a potential prodrug for treatment of the irritable bowel syndrome. Pharm. Res. 11, 17071711.

Nunes, K. P., Rigsby, C. S., and Webb, R. C. (2011). RhoA/Rho-kinase and vascular diseases: what is the link? Cell. Mol. Life Sci. 67, 3823-3836. doi: 10.1007/ s00018-010-0460-1

Oertling, H., Surburg, H., and Bertram, H. (2007). Applications of menthol in synthetic chemistry. Chem. Rev. 107, 2136-2164. doi: 10.1021/cr068409f

Olive, J. L., Hollis, B., Mattson, E., and Topp, R. (2010). Vascular conductance is reduced after menthol or cold application. Clin. J. Sport Med. 20, 372-376. doi: 10.1227/NEU.0b013e3181e57bca

Pan, Y., Thapa, D., Baldissera, L. Jr., Argunhan, F., Aubdool, A. A., and Brain, S. D. (2018). Relevance of TRPA1 and TRPM8 channels as vascular sensors of cold in the cutaneous microvasculature. Pflügers Arch. Eur. J. Physiol. 470, 779-786. doi: 10.1007/s00424-017-2085-9

Petrowitz, H. (1980). The effects of optical antipodes of menthol on termite species. Naturwissenschaften 67, 43-44.

Pozsgai, G., Bodkin, J. V., Graepel, R., Bevan, S., Andersson, D. A., and Brain, S. D. (2010). Evidence for the pathophysiological relevance of TRPA1 receptors in the cardiovascular system in vivo. Cardiovasc. Res. 87, 760-768. doi: 10.1093/ $\mathrm{cvr} / \mathrm{cvq} 118$
Rakieten, M. L. (1957). The effect of L-menthol on the systemic blood pressure. J. Am. Pharm. Assoc. 46, 82-84. doi: 10.1002/jps.3030460203

Rocha, J. T., Hipólito, U. V., Callera, G. E., Yogi, A., Filho, M., dos, A. N., et al. (2012). Ethanol induces vascular relaxation via redox-sensitive and nitric oxide-dependent pathways. Vascul. Pharmacol. 56, 74-83. doi: 10.1016/j.vph.2011.11.006

Roustit, M., Loader, J., Deusenbery, C., Baltzis, D., and Veves, A. (2016). Endothelial dysfunction as a link between cardiovascular risk factors and peripheral neuropathy in diabetes. J. Clin. Endocrinol. Metab. 101, 3401-3408. doi: 10.1210/jc.2016-2030

Ru, X. C., Qian, L. B., Gao, Q., Li, Y. F., Bruce, I. C., and Xia, Q. (2008). Alcohol induces relaxation of rat thoracic aorta and mesenteric arterial bed. Alcohol Alcohol. 43, 537-543. doi: 10.1093/alcalc/agn042

Schaefer, B. (2015). "Natural products in the chemical industry", in Synthesis, Vol. 47, ed. B. Schaefer (Berlin: Springer-Verlag), 1356-1356. doi: 10.1055/s-00341378701

Silva, D. F., De Almeida, M. M., and Chaves, C. G. (2015). TRPM8 channel activation induced by monoterpenoid rotundifolone underlies mesenteric artery relaxation. PLoS One 10:e0143171. doi: 10.1371/journal.pone.0143171

Sun, J., Yang, T., Wang, P., Ma, S., Zhu, Z., Pu, Y., et al. (2014). Activation of cold-sensing transient receptor potential melastatin subtype 8 antagonizes vasoconstriction and hypertension through attenuating RhoA/Rho kinase pathway. Hypertension 63, 1354-1363. doi: 10.1161/HYPERTENSIONAHA. 113.02573

Swandulla, D., Carbone, E., Sch, K., and Lux, H. D. (1987). Effect of menthol on two types of Ca currents in cultured sensory neurons of vertebrates. Pflügers Arch. Eur. J. Physiol. 409, 52-59. doi: 10.1007/bf00584749

Tajino, K., Matsumura, K., Kosada, K., Shibakusa, T., Inoue, K., Fushiki, T., et al. (2019). Application of menthol to the skin of whole trunk in mice induces autonomic and behavioral heat-gain responses. Am. J. Physiol. Regul. Integr. Comp. Physiol. 293, R2128-R2135.

Takaishi, M., Uchida, K., Suzuki, Y., and Matsui, H. (2016). Reciprocal effects of capsaicin and menthol on thermosensation through regulated activities of TRPV1 and TRPM8. J. Physiol. Sci. 66, 143-155. doi: 10.1007/s12576-0150427-y

Tawakol, A., Omland, T., Creager, M. A., Omland, T., and Creager, M. A. (2019). Direct effect of ethanol on human vascular function. Am. J. Physiol. Heart Circ. Physiol. 286, H2468-H2473.

Toda, N., Konishi, M., Miyazaki, M., and Komura, S. (1983). The effects of ethanol and acetaldehyde on dog arterial smooth muscle. J. Stud. Alcohol 44, 1-16. doi: 10.15288 /jsa.1983.44.1

Topp, R., Ledford, E. R., and Jacks, D. E. (2013). Topical menthol, ice, peripheral blood flow, and perceived discomfort. J. Athl. Train. 48, 220-225. doi: 10.4085/ 1062-6050-48.1.19

Topp, R., Winchester, L., Mink, A. M., Kaufman, J. S., and Jacks, D. E. (2011a). Comparison of the effects of ice and $3.5 \%$ menthol gel on blood flow and muscle strength of the lower arm. J. Sport Rehabil. 20, 355-366. doi: 10.1123/jsr.20.3.355

Topp, R., Winchester, L. J., and Schilero, J. (2011b). Effect of topical menthol on ipsilateral and contralateral superficial blood flow following a bout of maximum voluntary muscle contraction. Int. J. Sports Phys. Ther. 6, 83-91.

Turina, A., del, V., Nolan, M. V., Zygadlo, J. A., and Perillo, M. A. (2006). Natural terpenes: self-assembly and membrane partitioning. Biophys. Chem. 122, 101-113. doi: 10.1016/j.bpc.2006.02.007

Valente, A., Carrillo, A. E., Tzatzarakis, M. N., Vakonaki, E., Tsatsakis, A. M., Kenny, G. P., et al. (2015). The absorption and metabolism of a single L-menthol oral versus skin administration: effects on thermogenesis and metabolic rate. Food Chem. Toxicol. 86, 262-273. doi: 10.1016/j.fct.2015.09.018

Vladymyrova, I., Filippov, I., Kuliieva, I., Iurkevych, A., Skryma, R., Prevarskaia, N., et al. (2011). Comparative effects of menthol and icilin on the induced contraction of the smooth muscles of the vas deferens of normal and castrated rats. Fiziol. Zh. 57, 21-33. doi: 10.15407/fz57.04.021

Wang, H., Liu, S., Chao, P., and Lee, F. (2016). Menthol inhibiting parasympathetic function of tracheal smooth muscle. Int. J. Med. Sci. 13, 923-928. doi: 10.7150/ ijms. 17042

Wasner, G., Schattschneider, J., Binder, A., and Baron, R. (2004). Topical mentholĐa human model for cold pain by activation and sensitization of $\mathrm{C}$ nociceptors. Brain 127, 1159-1171. doi: 10.1093/brain/awh134 
Weil, A., Moore, S. E., Waite, N. J., Randall, A., and Gunthorpe, M. J. (2005). Conservation of functional and pharmacological properties in the distantly related temperature sensors TRPV1 and TRPM8. Mol. Pharmacol. 68, 518-527. doi: $10.1124 / \mathrm{mol} .105 .012146$

Wright, C. E., Laude, E. A., Grattan, T. J., and Morice, A. H. (1997). Capsaicin and neurokinin A-induced bronchoconstriction in the anaesthetised guinea-pig: evidence for a direct action of menthol on isolated bronchial smooth muscle. Br. J. Pharmacol. 121, 1645-1650. doi: 10.1038/sj.bjp.070 1319

Xiao, B., Dubin, A. E., Bursulaya, B., Viswanath, V., Jegla, T. J., and Patapoutian, A. (2008). Identification of transmembrane domain 5 as a critical molecular determinant of menthol sensitivity in mammalian TRPA1 channels. J. Neurosci. 28, 9640-9651. doi: 10.1523/JNEUROSCI.2772-08.2008

Xiong, S., Wang, B., Lin, S., Zhang, H., Li, Y., Wei, X., et al. (2017). Activation of transient receptor potential melastatin subtype 8. J. Am. Heart Assoc. 6, 1-17.
Yosipovitch, G., Szolar, C., Hui, X. Y., and Maibach, H. (1996). Effect of topically applied menthol on thermal, pain and itch sensations and biophysical properties of the skin. Arch. Dermatol. Res. 288, 245-248. doi: 10.1007/ bf02530092

Conflict of Interest: The author declares that the research was conducted in the absence of any commercial or financial relationships that could be construed as a potential conflict of interest.

Copyright (c) 2020 Silva. This is an open-access article distributed under the terms of the Creative Commons Attribution License (CC BY). The use, distribution or reproduction in other forums is permitted, provided the original author(s) and the copyright owner(s) are credited and that the original publication in this journal is cited, in accordance with accepted academic practice. No use, distribution or reproduction is permitted which does not comply with these terms. 